Article

\title{
Intra-Urban Mobility in the Estimation of Risk Scenarios by BTEX Emissions
}

\author{
Marco Antonio García-Zarate 1,2, María Evarista Arellano-García 3,*, Mariana Villada Canela ${ }^{2}$, \\ Patricia Aceves-Calderon 3, Ana Erika Ruiz-Arellano 4; Christine Alysse Von-Glascoe 5, \\ M. C. Arredondo Garcia ${ }^{6}$
}

${ }^{1}$ CICESE, Ensenada- Tijuana highway \#3918, Playitas, 22860 Ensenada, Mexico; E-mail: margarci@cicese.mx

2 Oceanology Research Institute, Universidad Autónoma de Baja California, Km. 103 Tijuana - Ensenada Highway Baja California 22860, Mexico; E-Mail: mvilladac@uabc.edu.mx

${ }^{3}$ Science Faculty, Universidad Autonoma de Baja California, Km. 103 Tijuana - Ensenada Highway Baja California 22860, Mexico; E-Mail: evarista.arellano@uabc.edu.mx; pat_aceves@uabc.edu.mx

${ }^{4}$ Faculty of Engineering, Architecture and Design, Universidad Autónoma de Baja California, Km. 103 Tijuana

- Ensenada Highway Baja California 22860, Mexico; erika.ruizarellano@gmail.com

${ }^{5}$ COLEF, Escenica Tijuana-Ensenada Km 18.5, San Antonio del Mar, 22560 Tijuana, Baja California, Mexico; E-Mail: christina.vonglascoe@gmail.com

${ }^{6}$ Marine Science Faculty, Universidad Autonoma de Baja California, Km. 103 Tijuana - Ensenada Highway Baja California 22860, Mexico; E-Mail: conchita@uabc.edu.mx

* Correspondence: evarista.arellano@uabc.edu.mx

\begin{abstract}
The population's mobility in urban areas is a necessary variable in the modeling of risk scenarios caused by atmospheric contamination. The inclusion of this concept makes static models more dynamic while considering people within a city to be an entity with complex mobility processes. We propose a conceptual and methodological tool to make the representation of the social, economic and territorial components, as well as the patterns in the population's mobility to delimitate risk areas for human health by exposure of contaminants. In the volatile organic compounds (VOC), benzene, ethylbenzene, toluene and xylene (BTEX) are amongst the most dominant substances in fugitive vapor emissions in gas stations (GS). In urban areas, the exposure to BTEX by residential proximity and proximity to other facilities, which cause intra-urban agglomeration, can impact and affect human health. This model seeks to facilitate the focalization, identification and prioritization of risk areas by BTEX environmental contamination. This article goes beyond de conceptual framework. It suggests methodological and instrumental aspects to be applied in other cities. The government agencies must consider these results when establishing rules, permissions and procedures to reduce environmental pollution for managing the risk in a complex urban environment.
\end{abstract}

Keywords: VOC; technological risk; exposure to risks; DRI; risk mapping; SIG; BTEX

\section{Introduction}

In the last few years, environmental pollution has become one of the most important matters worldwide. One of the branches of contamination is air pollution and corrective measure against public health problems [1]. Atmospheric contamination is defined as the presence of one or more pollutants or combination of these in the atmosphere. Atmospheric contamination can happen either by released gas or particulate matter which reduce both internal and external air quality. Some of these pollutant compounds can cause carcinogenic and non-carcinogenic effects on human health. The population is potentially exposed to this complex compound through air, dust, food and water. The effects of the volatile organic compounds (VOC) on human health due to gas stations (GS) may vary since they are made up of individual components that have genotoxic, carcinogen, haematotoxic, nephrotoxic, neurotoxic effects or act as endocrine disruptors [2]. 
Gasoline fume emissions are one of the main air pollutants in GS. Gasoline is a complex and variable compound of aliphatic hydrocarbons and aromatics low in molecular weight. The low-in-molecularweight aromatics BTEX is a very important group to take into account when talking about exposing the population and workers to these fumes. Benzene is one of the most important components of the BTEX group, from the toxicological point of view, since it is considered carcinogen for humans. The presence of benzene from GS is due to the emissions that happen during distribution, loading and unloading and transportation of gasoline [3-7].

BTEX studies show that personal exposure usually exceeds the concentration of pollution in the air. The level of exposure to VOCs depends on the proximity to the source of emission, especially indoors where people spend up to $90 \%$ of their time [8-18].

The BTEX group affects the lymphatic, haematopoietic, hepatic, renal and nervous systems (NS). It also causes leukemia associated with benzene exposure [19-27]. Out of all these effects, those targeted towards the nervous systems seem to be the most conspicuous and are probably the quickest to detect in situation of continuous or chronic exposure. The pulmonary alveoli are the finest area of absorption through which most of these compounds reach the blood [28].

Research on the evaluation of health risks due to toxic substances by anthropogenic processes in the environment is low because there is a great amount of listed pollutants in clean air, air also has a varied chemical nature and its geographic distribution is heterogeneous. One way to approach the lack of direct measuring data is to estimate toxic concentrations in the air outdoors using dispersion modeling techniques that can be obtained from different types of spatial and non-spatial data from various sources.

The evaluation of health risks by pollutants can be studied from different disciplines [29-31] and it is a qualitative and quantitative process which objective is to assign values, magnitudes and probabilities to adverse effects on the health of people who are exposed to dangerous chemicals. Research on the evaluation of urban risks tends to consider that the population is confined in their homes the entire day. For all this, the necessity arose to design a methodology of evaluation of risk that includes the human population, their intra-urban mobility patterns as well as other components in their ecosystem all in one process [32].

Since the 1970's, intra-urban mobility has been explored [33] associating it strongly with urban transport. Furthermore, it was linked to life quality and sustainable transport once the concept of sustainable intra-urban mobility was proposed [34].

Some authors consider intra-urban mobility to be in accordance with two main factors: size and shape of the city. In bigger cities people make longer trips but in smaller cities, where movement is spatially limited, there are a greater number of shorter trips [35]. Other authors mention that in developing countries mobility depends on the population's capacity to attain a home near their working place [36].

In this paper, we propose that intra-urban mobility is not only related to transport but to the different processes of everyday life that take place in a city. These processes drive people to leaving their domiciles to head on to schools, hospitals, work, recreation centers and malls. Intra-urban mobility is dynamic in terms of schedules and itineraries. This produces agglomeration of the population in certain places at particular hours especially during the morning. Also, most people stay at home overnight except when work requires them to be out.

Processes such as work, education, healthcare, commerce and recreation make intra-urban mobility more dynamic and generate agglomerations that can modify static risk models by atmospheric contamination where there is danger of contamination.

The method of proposal consists of a conceptual model that links the characteristics of a contaminated place with the possible receptors whether it is values or goods that are susceptible to damage and the processes that relate them, such as infrastructure, people exposed and mobility.

When an evaluation of risk from exposure to a specific substance is done, we analyze the toxic properties of a particular substance and the conditions of human exposure to said substance. All this to make sure of the possibility that the people exposed will develop negative effects and to characterize the nature of the effects that can arise in the future. Demographic growth and 
industrialization modify and increase the quantity and properties of toxic substances in accordance to time, which must be taken into account in risk studies [37].

A risk map of a community or geographical area shows the places, buildings, homes, schools, sanitary facilities and other constructions where people could be affected in case of hurricanes, earthquakes, tsunamis, floods, volcanic eruptions, avalanches and other natural threats and technological or environmental disasters. To create a risk map we need to determine the areas and elements that are at risk within a community or geographical area and organize them in a system of indicators that lets us represent the risk and its management on a state level. This facilitates identifying the essential aspects that characterize them from an economic and social perspective. The spatial risk analysis does not resolve the negative political and social complications that take place in decision making. What improves is the capacity of scientists and decision makers to identify, evaluate, control and reduce risks associated with human related activities.

\section{Methodology}

The methodology proposed contemplates various phases, the first being the compilation of sources of information based on their utility to build a geographic information system (GIS). The second is a design of some indicators set out based on the elements wished to be represented in the risk model. Another phase is the representation of different risk scenarios based on danger, exposure and vulnerability to determine risk areas. A detailed description of each of these phases will be represented from the case on risk scenarios by BTEX exposure in urban areas in Ensenada, Baja California. The geographical information was taken from various governmental agencies like Mexican Petrol (PEMEX), the National Population Council (CONAPO), the Secretariat of Public Education (SEP) and the National Institute of Statistics and Geography (INEGI). With this information we elaborated am attribute table as suggested by Bennett [38] using information relevant to the elaboration of the anthropogenic risk model on urban areas in Ensenada, Baja California.

The determination of BTEX emissions was done using an emission factor defined as the volume of raw material or fuel of a certain atmospheric pollutant [39]. Nowadays, there are many different sources to consult from to attain an emission factor as recommended by the AP-42 Compilation of Air Pollutant Emission Factors [40-41].

For this study, the risk was calculated by estimating exposure, dangers and vulnerability on a scale AGEB (Basic Geostatistical Area) level. For the evaluation, we determined a buffer of $300 \mathrm{~m}$ in radius [42-47] which made generating maps in GIS around each GS possible.

Layers with the information on the population's density that lives, studies, works and visits the facilities and their economic value have been overlapped on the map of the GS and buffer.

The data collected is represented by different units of measurement necessary for the risk evaluation of the GIS. Various thematic layers are made in the GIS with the different parameters and phenomenon necessary to estimate the exposure $(\mathrm{E})$, hazard $(\mathrm{H})$ and vulnerability $(\mathrm{V})$ that can be attributed to gasoline vapors emissions. The equation known as Disaster Risk Index (DRI) was used to determine the risk. It allows us to describe the severity of the risk for an area of study and it is determined by three components: hazard, exposure and vulnerability.

Here, hazard $(\mathrm{H})$ means the probability of a potentially dangerous technological or natural phenomenon, such as exposure to gasoline vapors, to happen within a specific period of time and a known area. On the other hand, exposure is the distribution of the population and material goods that can be affected by this hazard. It is possible to determine a spatial distribution of the risk since hazard, exposure and vulnerability present territorial variations.

According to Blaikie [48], vulnerability covers the characteristics of a person, or groups, in relation to their capacity to anticipate, face, resist and recover from a disaster. Vulnerability refers to the potential members of the population that could be affected and the economic and socio- economic systems that could be interrupted when a physical infrastructure is damaged or destroyed; [49].

In order to calculate social vulnerability, overlapped layered maps were created with the locations of fuel storage, storage capacity, population density, the information on important infrastructure for 
urban areas such as schools, hospitals and other type of facilities used for economic, social and commercial purposes.

The Disaster Risk Index (DRI), implemented by the Bureau for Crisis Prevention and Recovery (BCPR) for the United Nations Development Programme (UNDP), identifies the relative distribution of the exposure to threats and vulnerability factors when dealing with risks (PNUD/BCPR, 2004).

$$
\boldsymbol{D} \boldsymbol{R} \boldsymbol{I}=\frac{H+E+V}{3}
$$

Where:

$\mathrm{H}=$ Hazard

$\mathrm{E}=$ Exposure

$\mathrm{V}=$ Vulnerability

\section{Results and discussion}

\section{Hazard $(\mathbf{H})$}

For the hazard map, shown in figure 1, the values for $\mathrm{H}$ were calculated based on the quantity of annual sales of petrol based products of GS in different places in the area of study. In accordance to the probability of occurrence and the intensity of the hazard that could happen, it is used to calculate the intensity of the hazard while the number of storage locations is used to calculate the probability of the risk taking place in relation to the location of the GS. The hazard is the probability of occurrence of a physical phenomenon that could be dangerous to human lives and lead to injuries, damage to property or de deterioration of natural ecosystems.

$$
H=\frac{\text { Intensity } X \text { Probability }}{T A}
$$

$\mathrm{TA}=$ the total area of study

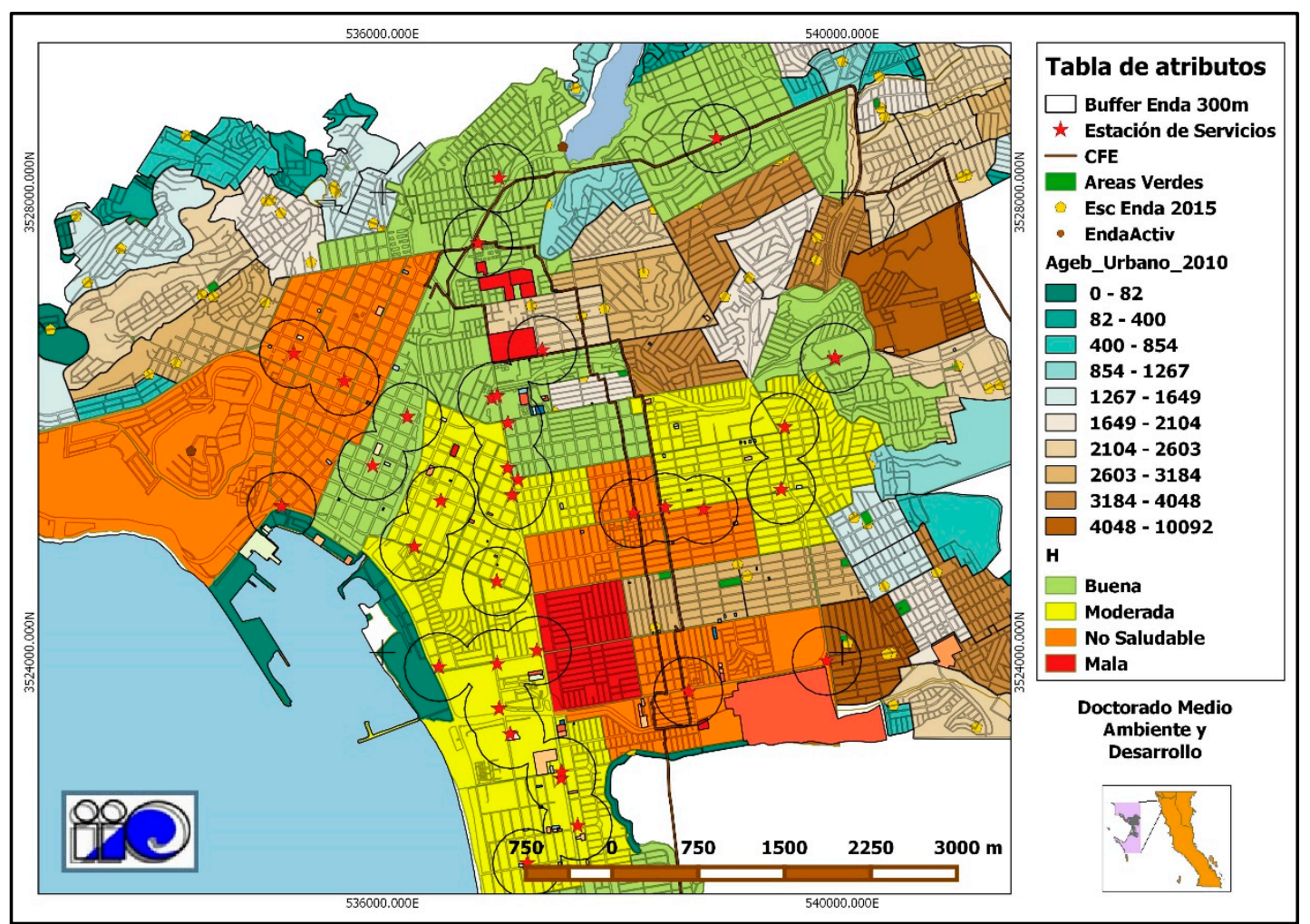

Figure 1. Hazard (H) Map 


\section{Exposure (E)}

For the exposure map, shown in figure 2, we took the number of people per unit area of the area of study, in other words, population density calculated with the following formula:

$$
E=\frac{\text { Population }}{T A}
$$

Where:

$\mathrm{TA}=$ the total area of study

The figure shows that the exposure is the number of people related to the assets exposed to disasters present in the affected risk areas subjected to potential loses.

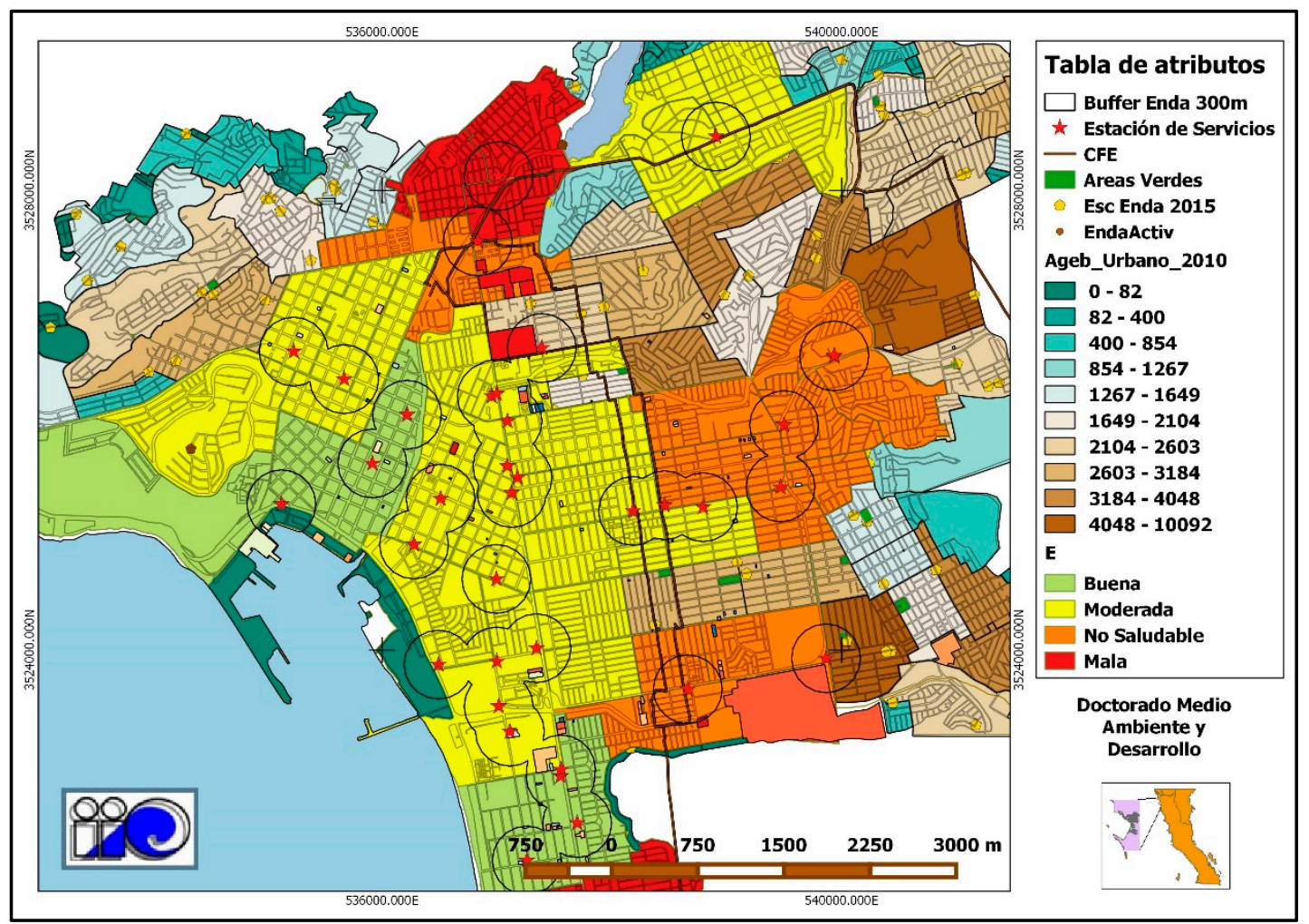

Figure 2: Exposure (E) Map

\section{Vulnerability (VI)}

For the vulnerability map, multiple layers were overlapped, one for each VI component as shown in Table 1. Vulnerability is the level of loss in an element or group of elements under risk as a result of probable occurrence of a disastrous event, estimated in terms of lives, goods, products or infrastructure located in the area exposed to hazard. In this case, the estimation of the values for vulnerability was calculated off of different units for different types of hazards, as shown in figure 3.

$$
V I=\frac{S V I+P V I+E n V I+C I V I+I V W o r k+E s c V I}{6}
$$


Table 1: VI Components

\begin{tabular}{|c|c|c|}
\hline Element & Description & Expression \\
\hline SVI & $\begin{array}{l}\text { Social vulnerability is associated with the lack of } \\
\text { resources to mitigate or face the disaster or the } \\
\text { population that lacks the ability to self-recuperate. }\end{array}$ & $\begin{array}{l}\qquad S V I=\frac{\text { Población }(14>0<65) X D A}{A T_{A}} \\
\text { DA: Damaged location within buffer } \\
\mathrm{AT}_{\mathrm{A}}=\text { Total AGEB area }\end{array}$ \\
\hline PVI & $\begin{array}{l}\text { Physical vulnerability is expressed in terms of the } \\
\text { exposure to unsafe conditions where the population } \\
\text { of the area of study is dangerously close to the } \\
\text { potential source of danger. }\end{array}$ & $\begin{array}{l}\qquad P V I=\frac{\text { Población } X D A}{A T_{A}} \\
\text { DA: Damaged location within buffer } \\
\text { AT }_{A}=\text { Total AGEB area }\end{array}$ \\
\hline EnVI & $\begin{array}{l}\text { Environmental vulnerability is defined as the } \\
\text { potential environmental degradation caused by } \\
\text { danger. It can be calculated as the amount of } \\
\text { contaminants produced per unit area. }\end{array}$ & $\begin{array}{l}\qquad E n V I=\frac{A P X P F P}{A T_{A}} \\
\mathrm{AP}=\text { Annual gasoline sales } \\
\mathrm{PFP}=\text { Benzene emitted to the atmosphere due to gas sales annually } \\
\mathrm{AT}_{\mathrm{A}}=\text { Total AGEB area }\end{array}$ \\
\hline CIVI & $\begin{array}{l}\text { Critical infrastructure vulnerability such as } \\
\text { educational facilities, hospitals, transport, highway } \\
\text { and train track segments that are exposed to probable } \\
\text { fire related disasters. }\end{array}$ & $\begin{array}{l}\qquad C I V I=\frac{I C X D A}{A T_{A}} \\
\text { IC: Important infrastructure within the buffer } \\
\text { DA: Damaged location within buffer } \\
\mathrm{AT}_{\mathrm{A}}=\text { Total AGEB area }\end{array}$ \\
\hline IVwork & $\begin{array}{l}\text { Vulnerability of workers within the buffer near the } \\
\text { possible sources of danger }\end{array}$ & $\begin{array}{l}\qquad I V \text { work }=\frac{N T X D A}{A T_{A}} \\
\text { NT: Number of workers within the buffer } \\
\text { DA: Damaged location within buffer } \\
\mathrm{AT}_{\mathrm{A}}=\text { Total AGEB area }\end{array}$ \\
\hline EscVI & $\begin{array}{l}\text { Vulnerability of students within the buffer near the } \\
\text { possible sources of danger }\end{array}$ & $\begin{array}{l}\qquad E s c V I=\frac{A X D A}{A T_{A}} \\
\text { A: Student population within the buffer } \\
\text { DA: Damaged location within buffer } \\
\mathrm{AT}_{\mathrm{A}}=\text { Total AGEB area }\end{array}$ \\
\hline
\end{tabular}


Taking into account the population currently exposed, education facilities (that operate throughout the day from seven in the morning to eight at night), as well as the mobility pattern of most of the residents within urban areas, it is likely that only a small amount of the workers actually work in the same AGEB in which they spend the night limiting their ability to respond to potential exposure.

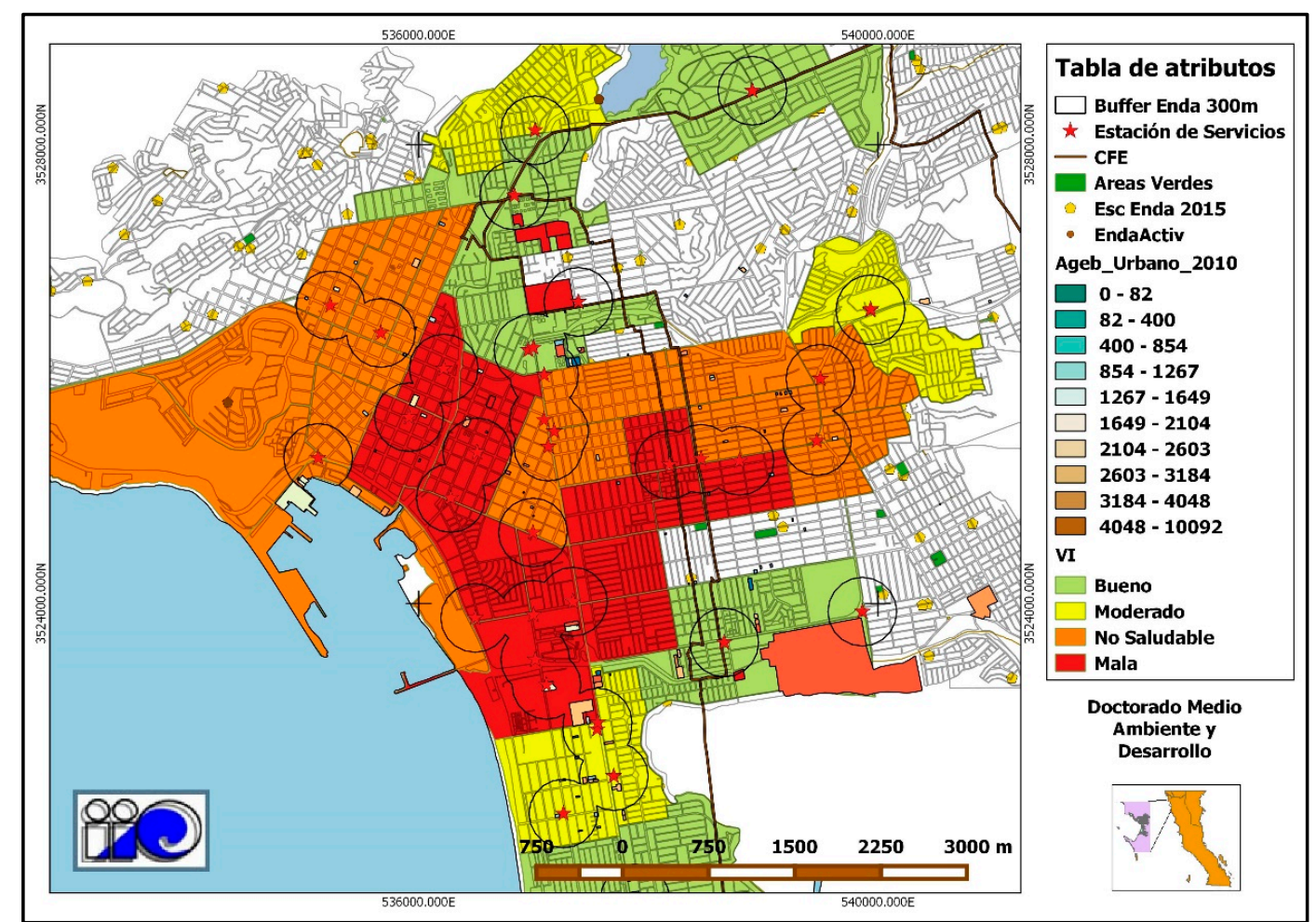

Figure 3. Vulnerability (V)

\section{Final considerations}

The main risk values in relation to population's vulnerability can be extracted from the spatial and semantic analysis used when selecting the locations for GS in order to attain a list of geographic objects based on their vulnerability degree depending on the type and magnitude of the environmental contamination parameters. For this reason, it is crucial to have the precise construction data, the amount of people (customers and workers), to be able to evaluate their vulnerability accurately.

Composite indices are calculated for the three main contributors to risk.

All the indicators that have some kind of relation to danger are put together in a linear combination to make up the risk index.

In the previous figures, three different indicators to attain the risk were shown. Each one of these events has a different radio of damage and affects different geographic objects. Although, as we can see, the radio of damage to population susceptible to inhaling gasoline vapors (BTEX) varies in relation to calculated parameters for each variable. This will allow the identification of houses near the exposure and later on will include schools, hospitals, meeting places and lastly, places like industries.

The obtained lists indicate the exact locations to prioritize and where more population is affected in case of an event, meaning we can identify the areas where a significant number of high vulnerable 
people live or work. In order to get the relative values for the indicators, these must me normalized in relation to maximum, minimum, media and standard diversion.

The purpose for this is to eliminate the influence of the indicator's units making the indicators stable in relation to their units, magnitudes and dispersions.

A weighing coefficient is determined in each indicator to represent their relative contribution to risk. The weighing coefficients for the Disaster Risk Index (DRI) are determined using a direct and subjective evaluation done by those who apply this methodology (Figure 4). The areas where the houses are located are shown and the influenced areas by potentially dangerous activities such as the people who work within an AGEB and schools with a high number of students are overlapped.

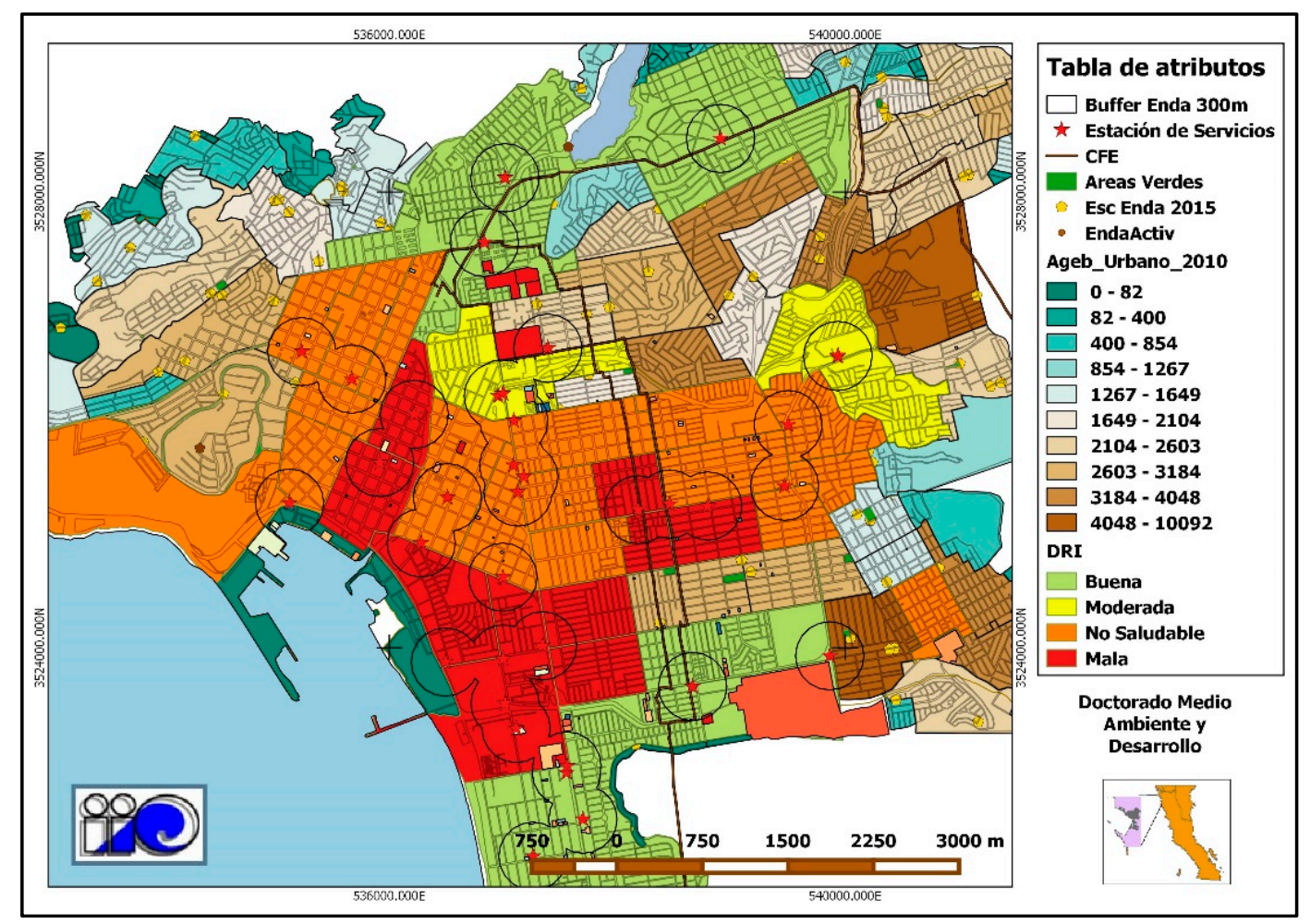

Figure 4. The weighing coefficients for the Disaster Risk Index (DRI)

To face the discrepancies about the health risks associated with air pollution for the groups vulnerable to volatile organic compounds (VOCs), this research allows us to identify the areas affected by the air pollution in the community and the people exposed in the urban areas of Ensenada, the health risks estimated to result from two volatile organic compounds emitted locally (benzene and ethylbenzene), as well as neurological and respiratory effects coming from benzene, toluene, xylene (BTEX) that exceed the EPA risk parameters in various communities. These findings have emphasized the need to look further into the disparity in the health risks related to air pollution for the disadvantaged groups. This study also demonstrates that the air pollution hotspots can give important information to investigate the effects atmospheric contamination has on human health.

VOCs include a variety of chemical products that can be harmful to human health and the environment. The air quality has become a topic of concern which is related to the fume emissions of BTEX found in urban environment and can affect people who live and work within the buffer exposed to volatile organic compounds. 
The results, which can be debatable, offer a first look at the territorial problem and can be useful to set future preventive interventions and planning from the GS authorities.

\section{Recommendations for intra-urban mobility}

On the topic of population density in urban areas, the concept of intra-urban mobility needs to be reconsidered, as well as public transport and other aspects to life in the city since people leave the places they spend the night at to go to work, study or recreate generating agglomerations within the urban perimeter where environmental conditions due to exposure by contaminants are a threat to human health.

Managing a system with a transparent geographic information filled data base, comprehensive and updated, must include indicators of urban development in the local, regional, state and federal levels to plan interventions, evaluate and monitor their impacts to provide a more precise and fast offering of public services that can lead to a better assessment of environmental risks.

The urban development decision makers can use these systems to determine and visualize the desirable urban growth, calculate costs for new infrastructure and identify areas with public service and social protection needs. Clear and accessible ground information is crucial for the public sector and private initiative to have the tools to incentivize the urban densification. This will allow the establishment and control of urban expansion limits and the planning of city growth. At the same time, it will provide backup for public policies by creating transparency related to the government and build trust in public institutions where citizens may participate in public debates about how and up to where their city should grow.

The main challenge for interurban mobility is the quick urban growth caused from high migration rates and the proliferation of irregular settlements, as well as the lack of connection between the different academic institutions that collect data with the municipal, state and federal governments, which causes decentralized information that is hard to locate.

\section{Conflict of Interests}

The authors declare that there is no conflict of interests regarding the publication of this paper.

\section{Reference}

1. Ferrier N, Haque E, 2013. Hazards risk assessment methodology for emergency managers: a standardized framework for application Nat Hazards, vol. 28, pp. 271-290.

2. ATSDR (Agency for Toxic Substances and Disease Registry), 2009. Toxicological Profile for Carbon Monoxide. Atlanta, Georgia

3. Periago, J.F.; Zambudio, A.; Prado, C. Evaluation of environmental levels of aromatic hydrocarbons in gasoline service stations by gas chromatography. J. Chromatogr. 1997, 778, 263-268.

4. Haro-Garcia L. "et al" (2012). Alteraciones hematologicas en trabajadores expuestos ocupacionalmente a mezcla de benceno-tolueno-xileno (BTX) en una fábrica de pinturas. Revista Peruana Médica Experta en Salud Pública. 29(2), 181-187

5. WHO (April 1999). IARC Monographs on the Evaluation of Carcinogenic Risks to Humans,Some Industrial Chemicals and Dyestuffs. WHO-IARC. 29: 93

6. Gil Hernández F. (2012). Toxicología industrial (II). Toxicidad de los disolventes, En A. Pla Martínez (Editor), Tratado de Medicina del Trabajo. pp: 759-760. 2ª․ Edición. España: Elsevier-Masson 
7. Popovic D. (June 2011). Assessment of Environmental Exposure to Benzene: Traditional and New Biomarkers of Internal Dose. In LOVREGLIO, Piero “et al" (Eds.). Air Quality -Models and Applications. pp. 322-340. 1a Edition. USA. Intechopen

8. Akland GA, Schwab M, Zenick H, Pahl D. 1997. An interagency partnership applied to the study of environmental health in the Low Rio Grande Valley of Texas. Environ Int 23:595-609.

9. Clayton CA, Pellizzari ED, Whitmore RW, Perritt RL, Quackenboss JJ. 1999. National Human Exposure Assessment Survey (NHEXAS): distributions and associations of lead, arsenic and volatile organic compounds in EPA Region 5. J Expo Anal Environ Epidemiol 9(5):381-392

10. Cohen M, Ryan B, Ozkaynak H, Epstein P. 1989. Indoor/outdoor measurements of volatile organic compounds in the Kanawha Valley of West Virginia. J Air Pollut Control Assoc 39:1086-1093.

11. Kinney PL, Chillrud SN, Ramstrom S, Ross J, Spengler JD. 2002. Exposure to multiple air toxics in New York City. Environ Health Perspect 110(suppl 4):539-546.

12. Periago, J.F.; Prado, C. Evolution of occupational exposure to environmental levels of aromatic hydrocarbons in service stations. Ann. Occup. Hyg. 2005, 49, 233-240.

13. Little, S.; Cram, G. Atmospheric benzene concentrations near petrol service stations in Middlesbrough. Clean Air 1995, 25, 140-147.

14. U.S. EPA (U.S. Environmental Protection Agency). 1987. Health and Environmental Effects Profile for Pyrene. Prepared by the Environmental Criteria and Assessment Office, Office of Health and Environmental Assessment, U.S. Environmental Protection Agency, Cincinnati, OH, for the Office of Solid Waste and Emergency Response. ECAO-CIN-P277.

15. Weisel CP. 2002. Assessing exposure to air toxics relative to asthma. Environ Health Perspect 110(suppl 4):527-537.

16. Bahrami, A.R.; Jafari, A.J.; Ahmadi, H. 2007. Comparison of benzene exposure in drivers and petrol stations workers by urinary trans, trans-muconic acid west of Iran. Ind. Health, 45, 396-401.

17. Tunsaringkarn, T.; Siriwong, W.; Rungsiyothin, A.; Nopparatbundit, S. Occupational exposure of gasoline station workers to BTEX compounds in Bangkok, Thailand. Int. J. Occup. Environ. Med. 2012, 3, 117-125.

18. Hartle, R. Exposure to methyl tert-butyl ether and benzene among service station attendants and operators. Environ. Health Perspect. 1993, 101, 23-26.

19. Chen R, Semple S, Dick F, et al. 2001. Nasal, eye, and skin irritation in dockyard painters. Occup Environ Med; 58:542-3.

20. Kaufman DW, Anderson TE, Issaragrisil S. Risk factors for leukemia in Thailand. Ann Hematol. 2009; 88(11):1079-1088.; 74(1):64-69.

21. Richardson DB. Temporal Variation in the Association between Benzene and Leukemia Mortality. Environ Health Perspect. 2008; 116(3):370-374.

22. Smith MT, Jones RM, Smith AH. Benzene Exposure and Risk of Non-Hodgkin Lymphoma. Cancer Epidemiol Biomarkers Prev. 2007; 16(3):385-391.

23. Collins JJ, Ireland B, Buckley CF, Shepperly D. 2003. Lymphohaematopoeitic cancer mortality among workers with benzene exposure. Occup Environ Med.; 60:676-679.

24. Hayes RB, Yin SN, Dosemeci M, et al. Benzene and the dose-related incidence of hematologic neoplasms in China. Chinese Academy of Preventive Medicine-National Cancer Institute Benzene Study Group. J Natl Cancer Inst. 1997; 89:1065-1071.

25. Rinsky RA, Hornung RW, Silver SR, Tseng CY. Benzene exposure and hematopoietic mortality: a long-term epidemiologic risk assessment. Am J Ind Med. 2002; 42:474-480.

26. Kipen HM, Cody RP, Crump KS, Allen BC, Goldstein BD. Hematologic effects of benzene: a thirty-5 year longitudinal study of rubber workers. Toxicol Ind Health. 1988; 4:411-430.

27. Bollati V, Baccarelli A, Hou L, et al. 2007. Changes in DNA methylation patterns in subjects exposed to lowdose benzene. Cancer Res. 67:876-880

28. MORENO GRAU, M. D. 2003. Toxicología ambiental. Evaluación del Riesgo para la Salud Humana. Mc. Graw Hill. / Interamericana de España S.A.U. 
29. Campos, A. 2002, Algunas consideraciones sobre los "mapas de riesgo" en: CRID Centro de Información sobre Desastres América. Bibliodes № 30 Pág. 46

30. Morales-Terres, I.M.; Doval-Minarro, M.; Gonzalez-Ferradas, E.; Baeza-Caracena, A.; Barbera-Rico, J. Assessing the impact of petrol stations on their immediate surroundings. J. Environ. Manage. 2010, 9, 27542762.

31. Ruchirawat, M.; Navasumrit, P.; Settachan, D. Exposure to benzene in various susceptible populations: Coexposure to 1, 3-butadiene and PAHs and implications for carcinogenic risk. Chem.-Bilo. Inter. 2010, 184, 6776.

32. Torres, A.; Espinosa-Reyes, G.; Ilizaliturri, I.; González, D.; Razo, I.; Mejía, J.; Díaz-Barriga, F. 2005. Desarrollo de una metodología para la evaluación integrada de riesgos ambientales en sitios peligrosos de México. Instituto Nacional de Ecología.México, D.F. 130 p.

33. Weinberg, D. H. (1979). The determinants of intra-urban household mobility. Regional Science and Urban Economics, 9(2), 219-246.

34. da Silva, A. N. R., da Silva Costa, M., \& Macedo, M. H. (2008). Multiple views of sustainable urban mobility: The case of Brazil. Transport Policy, 15(6), 350-360.

35. Kang, C., Ma, X., Tong, D., \& Liu, Y. (2012). Intra-urban human mobility patterns: An urban morphology perspective. Physica A: Statistical Mechanics and its Applications, 391(4), 1702-1717.

36. Alananga Sanga, S. 2015. Intra-urban residential mobility and tenants' workplace choices in Kinondoni municipality. Habitat International, 49, 45-55

37. Diagnóstico de Peligros e Identificación de Riesgos de Desastres en México. (DPIRDM), 2001. CENAPRED.

38. Bennett, D. A. 1997. A framework for the integration of geographical information systems and model base management, International Journal of Geographical Information Science 11(4): 337-357.

39. Environmental Protection Agency, EPA. 2003. Air Quality Index. Aguide to Air quality and your health. Washington: EPA. (EPA-454/k-03-002)

40. US EPA. 1995. (United States Environmental Protection Agency) Compilation of Air Pollutant Emission Factors AP-42. 5th Edition, Office of Air Quality Planning and Standards, Research Triangle Park, NC. 1995.

41. US EPA. 1995 . (The United States Environmental Protection Agency), Compilation of Air Pollutant Emission Factors-Stationary Point and Area Sources. Research Triangle Park, NC, AP-42.

42. Terres, I.M.M., Minarro, M.D., Ferradas, E.G., Caracena, A.B., Rico, J.B. 2010. Assessing the impact of petrol stations on their immediate surroundings. Journal of Environmental Management 91, 2754-2762

43. Silva, F.L.D., dos Santos, J.R., Moita, J.M., da Silva, R.L.G.D., Flumignan, D.L., de Oliveira, J.E. 2009. Determination of benzene, toluene, ethylbenzene and xylenes in commercial gasoline from Piaui State. Quimica Nova 32, 56-U64

44. Santos, M. D. A., Tavora, B. E., Koide, S., \& Caldas, E. D. 2013. Human risk assessment of benzene after a gasoline station fuel leak. Revista de Saúde Pública, 47(2), 335-344.

45. Karakitsios, S.P., Delis, V.K., Kassomenos, P.A., Pilidis, G.A., (2007). Contribution to ambient benzene concentrations in the vicinity of petrol stations: estimation of the associated health risk. Atmospheric Environment; 41, 1889 -1902

46. Correa SM, Arbilla G, Marques MRC, Oliveira KMPG, 2012. The impact of BTEX emissions from gas stations into the atmosphere. Atmospheric Pollution Research; 3: 163-9.

47. Hystad, P., Setton, E., Cervantes, A., Poplawski, K., Deschenes, S., Brauer, M., Demers, P. (2011). Creating national air pollution models for population exposure assessment in Canada. Environmental health perspectives, 119(8), 1123.

48. Blaikie, P., Cannon, T., Davis, I. and Wisner, B. 1994. At Risk: Natural Hazards, People's Vulnerability, and Disasters. London: Routledge.

49. Índice de Riesgo de Desastre Sismico “EDRI” (IDNDR1990-2002)

(C) 2016 by the authors; licensee Preprints, Basel, Switzerland. This article is an open access article distributed under the terms and conditions of the Creative Commons by Attribution (CC-BY) license (http://creativecommons.org/licenses/by/4.0/). 